\title{
The Influence of Macroeconomic Factors in the Failure of Returning the Bank Credits in Kosovo
}

\author{
Nagip Skenderi \\ Asstt.Prof., University of Prishtina, Faculty of Economics; Email: nagipskenderi@hotmail.com \\ Xhavit Islami \\ University of Prishtina, Faculty of Economics; Email: xhavit.islami@uni-pr.edu \\ Enis Mulolli \\ University of Prishtina, Faculty of Economics; Email: enis.muloll@uni-pr.edu
}

\section{Doi:10.5901/mjss.2016.v7n1p320}

\section{Abstract}

The possibility of non- returning the credits is a challenge faced by all banks. Giving back the taken credits is an important issue for the efficient operation of the banking system. Lending is one of the main uncertainties of the banking system, as the paying of credits rarely can be completely guaranteed. Very often these questions are asked: Which are the factors that have an impact in the failure of bank credit repayment? What policies should be pursued to stimulate the return of bank loans? The research aimed to analyze the impact of macroeconomic factors (gross domestic product, interest rates, unemployment, inflation) and credit policies (the time of maturity and grace period), in the failure of returning the credits in the banking sector. The results of the research are processed on 242 questionnaires; these data were processed with the help of SPSS v 21 program. By growing the gross domestic product, maturity interval, and application of grace period there might be a decrease of non-performing loans, whereas increasing interest rate, inflation and unemployment norms increases the rate of nonperforming credits in relation to total credits in Kosovo. This study argues what is needed for Kosovo's banking system and presents the ideas of sustainable development of the banking sector in relation to non-performing loans, and credit policy reorientation.

Keywords: Gross domestic product, the credit policy, the banking system, non-performing credits, macroeconomic.

\section{Introduction}

Dealing with the problem of non-returning the credit is a big challenge and its careful treatment is necessary all around the world, because an uncontrolled growth in credits with problem would have sent the entire banking system in a possible bankruptcy and the entire financial system in a collapse. The failure in returning the bank credits is one of the main risks which influences the banking system stability. The banks in Kosovo have had a fragile banking system through the transition process and NPL has marked a significant growth in the last five years, which comes as a result of influence of macroeconomic factors in the place. Such situation with a fragile economy, increases the need for studying macroeconomic variables and their influence in NPL. In the last years Kosovo has marked a slowly increase of credits, in the first half of 2014 has been showed the first indicators of reclamation activity to give credits in Kosovo.

In June 2014, the total sum of credits reached 1.89 billion euro, which presents the annual growth to $3.5 \%$, which is higher than the annual norm of increase to $2.8 \%$ in June 2013 (CBK, 2014). The credits risk is one of the main risks through which it is exposed the banking system of Kosovo.

Comparing with a year before, the credits risk has marked an increase, in June 2014 the report of non performing credits in comparison with all credits amounted to $8.2 \%$ from 7.8\% in June 2013 (CBK, 2014).

\section{The Case of Study}

In this research it is aimed to evaluate the macroeconomic factors' impact in the failure to return the bank credits in Kosovo in the period 2010-1014. Also, to show the impact of macroeconomic factors (GDP, interest norm, inflation rate 
and the unemployment rate) and credit policies (maturity and grace period) in increasing non-performing loans in Kosovo. Cases studied in the research:

- The influence of macroeconomic factors: GDP, interest norm, inflation rate and the unemployment rate and

- $\quad$ The Impact of lending policies, maturity, and grace periods, in increasing non-performing loans in Kosovo

\section{Literature Review}

In literature review, the findings have been presented from the browsing literature and from the research conducted by the authors and other institutions concerning the impact of macroeconomic factors in the failure to return the bank credits.

The academic literature confirms a strong relationship in between the macroeconomic factors and NPL. The main factors which have been researched in different places are: annual GDP norm, the real interest norm, annual norm of inflation, unemployment level, the real course of exchange, the banking risks and so on. Bofondi and Ropele (2011), have analyzed the influence of macroeconomic descriptors in banking credit value in Italy for the period 1990-2010. According to this study, the quality of banking credits can attribute to a limited number of macroeconomic factors as the general economic condition, the scale of depts and the borrowing costs. The change in these general macroeconomic conditions affects the quality of loans.

Louzis et al. (2010), have analyzed the banking sector in Greek, where there have been studied macroeconomic factors (the real norm of GDP, unemployment level and the real interest norm), for the period 2003-2009. The study shows that the quality of banking credits in Greek is tied with macroeconomic factors (GDP, unemployment norm and interest norm) as well as the management quality. Salas and Saurina (2002), after a study in the banks of Spain have found that the variation of bad loans is explained with a real growth of GDP, bank size, capital report and with the power of market.

For a relationship in between macroeconomic factors and the quality of loans there are a lot of theoretical models, where it is explained the economic cycles and banking stability. Expansive economy is characterized with a low number of bad loans, like the consumers, likewise the companies have enough incomes to cover their depts in pre-arranged time, whereas the economy in recession has a positive impact on increasing the bad depts. In general, theoretical models of business cycles with a financial role offer a good basis for the basis of modeling NPL, because they explain the cyclical nature of the business and the risk of failure in repayment of the loans (Williamson, 1987).

Lawrence (1995) examines the theoretical literature regarding life-cycle consumption model and introduces explicitly the probability of default. This model implies that borrowers with low incomes have higher rates of default due to increased risk of facing unemployment and being unable to settle their obligation. Besides that, in order to maintain the credit balance, the banks charge higher rates of interest rates to riskier clients.

Rinaldi and Sanchis - Arellano (2006) extended Lawrence's model by assuming that agents lend loans in order to invest in real or financial income. They argue that the possibility of not paying on time depends on the actual income and the unemployment rate, which is associated with the level of uncertainty of future revenue and lending rate.

According to Nkusu, (2011) the impact of inflation in NPL can be vague. He has explained that the relationship between them can be positive and negative.

On the one hand, it indicates that high inflation may make the payment of debt easier by reducing the real value of the loan paid, but on the other hand high inflation can reduce the real income of the borrower, since salaries are undecided. Further, Nkusu explains that in countries where the changing rates of inflation are higher, it may lead to higher rates of interest, a strategy designed for monetary policy to fight inflation. According to him, NPL have a central role in the relations between the credit market and the macro - financial factors.

A general explanation for the relationship of GDP and NPL provided by the authors ( Salas and Suarina, 2002; Ryan and Dhal , 2003; Fofack , 2005; and Jimenez and SAURINA, 2005) who claimed that an increase in real GDP will impact on revenue growth which improves the ability of the borrower to pay the loan. On the other hand, when the economy has stagnated the level of loans with problem is likely to increase as a result of rising unemployment, also it will result in increasing the difficulties of borrowers to repay the loan. When there is a decline in the economy (when there is a negative growth of GDP) the level of bad debts will grow. According to them, unemployment is positively related with NPL.

According to a study conducted in Africa is argued that economic growth (GDP) and the increase in real interest rates are the main determinants of bad loans (Fofack, 2005).

A study on factors affecting NPL in Islamic banks in Malaysia for the period 2007-2009 is made from Adebola et al. (2011), the results showed that long-term relationship between the norms of interest and non-performing loans is positive.

NPL problems arise when economic growth is converted into discounts, then the interest norms and risk is 
increased (Espinosa and Prasad, 2010). Macroeconomic factors, which were found to affect the quality of banks' assets, including exchange rate, interest and inflation rate (Louzis, Vouldis and Metaxas, 2010).

\section{Methodology}

To accomplish this study a methodology consisting from a combination of primary and secondary data has been used. A considerable part of secondary data were assured through using the exsisting literature of NPL, through consulting reports and important surveys for the impact of the factors in NPL.

For empirical analysis of this study, the data have been gathered from two self-administred questionnairs: one questionnaire was filled by the borrowers, expressing their views on the impact of macroeconomic factors and credit policy in NPL. All participants are borrowers in various banks operating in Kosovo, who have failed to return the loans in the pre-arranged time. 161 questionnaires were completed, the data have entered in the regression analysis and correlation. From these participants $53 \%$ of them are as individual borrowers (59\% men and $41 \%$ women) and $47 \%$ are legal entities which are borrowed as businesses, enterprises as business activity (27\% of service businesses, $13 \%$ manufacturing businesses, $49 \%$ commercial business, $11 \%$ construction businesses).

And the second questionnaire was distributed to the different bank employees operating in Kosovo, to express their views regarding the impact of macroeconomic factors in NPL increased in Kosovo . 81 questionnaires were filled, whose data were entered into SPSS for analysis.

To analyze this survey the program SPSS v. 21 has been used. The analysis was done with regression and correlation. The scale used in the questionnaire is based on a 5 -point Likert scale $(1=$ strongly disagree, $2=$ slightly disagree, 3 = neutral, 4 = agree, 5 = strongly agree).

\section{The Relationship between Macroeconomic Factors and NPL in Kosovo (2010-2014)}

In this part of the survey some important data will be presented regarding the impact of macroeconomic factors (GDP, interest rate, inflation rate and unemployment rate) in the increase of non performing loans, these data are gathered from secondary resources. Comparing with a year before, the credit risks have marked an increase, where in June 2014 the report of Non-performing loans of the total number of credits has reached to $8.2 \%$ from $7.8 \%$ compared with the June 2013, which means that it has marked a growth from $0.4 \%$ in the same periods of time (BQK 2014).

Gross of inner product - According to the same report GDP for a five -year period has had this course $(2010,3.3$ $\%$; in $2011,4.4 \%$; in $2012,2.8 \%$; in 2013, $3.4 \%$; and in 2014, 3.0 \% ), from these data is shown a slight increase of GDP in 2011 , whereas in 2014 there is a decrease in comparison with the previous year (CBK , 2014).

NPL in Kosovo in relation with total loans expressed as percentage during the period 2010-2014 are as follows : $(2010,5.8 \%$; in 2011 , 5.7\% ; in 2012, $7.4 \%$; in 2013, $8.5 \%$; in $2014,8.2 \%$ ) according to the data in 2013 was the highest rate of NPL (WB , 2014). As it is showed in Figure 1, it is expressed through graphic the relationship between GDP and NPL in Kosovo for the period 2010-2014, in general is presented a negative relationship between these two variables, which means that with the GDP increased NPL is reduced, an exception is made in the year 2014 which have an entitled report.

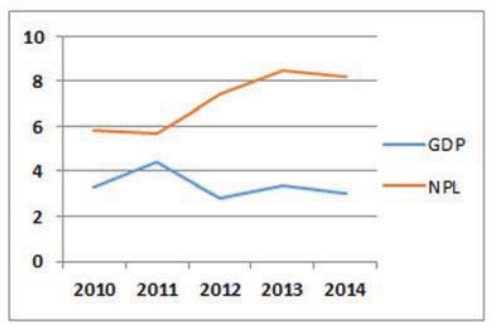

Figure 1.

Source: IMF \& WB (2014), modified by authors

Inflation rate - in Kosovo has decreased continuously in the period 2010-2014 (2010 , $3.5 \%$; in $2011,7.3 \%$; in 2012 , $2.5 \%$; in $2013,1.8 \%$; in $2014,0.4 \%$ ), the highest rate of inflation is recorded in 2011 , and still continued to decrease 
(WB , 2014) . Figure 2 graphically shows the link between the rate of inflation and NPL.

The inflation rate has two effects associated with NPL: a) indicates that high inflation may make easier the payment of debt by reducing the real value of the loan to pay; b) high inflation can reduce the real income of the borrower , since salaries are undecided ( Nkusu, 2011).

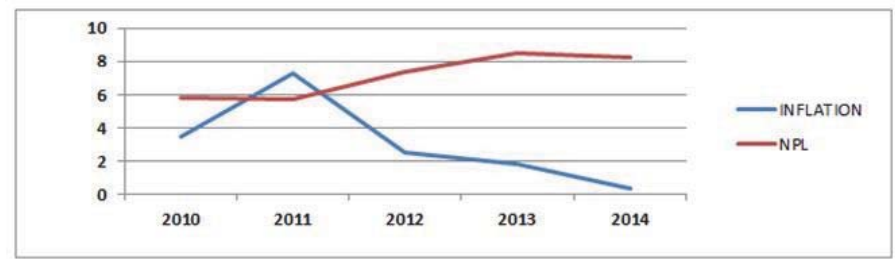

Figure 2.

Source: (WB, 2014), modified by the authors

Interest rate - for loans in Kosovo for the period 2010-2014 (2010, $14.3 \%$; in 201, $13.9 \%$; in 2012, 12.9 \%; in 2013, $11.1 \%$; in $2014,9.2 \%$ ) in Kosovo since 2010 interest rate has a continued decrease (WB , 2014).

Interest rates on loans were characterized by the downward trend during the first half of 2014. There were decreases to $10.6 \%$ in June 2014 by (12.0\% in June 2013), (CBK, 2014). While real interest rates for the period 2010$2014(2010,10.3 \%$; in 2011 , $7.0 \%$; in 2012, $11.1 \%$; in2013 , $8.7 \%$; in 2014, $12.5 \%$ ) (WB , 2014).

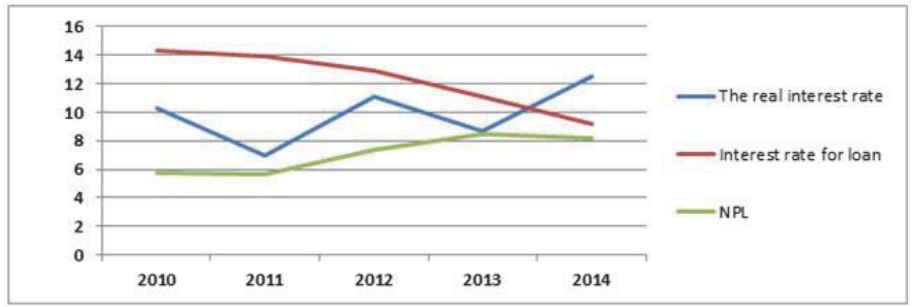

Figure 3.

Source: World Bank (2014), modified by the authors

In Figure 3, it is shown graphically, the report concerning interest norms for loan, real interest rate and non-performing loans for the past five years. There is seen that the relationship between real interest rate and NPL is fully in right relationship since 2010-2012, with the change of the real interest rate it has also changed the rate of NPL in the same direction.

Unemployment- The latest Labor Force Survey (LFS), showed that the Kosovo has an unemployment rate of about $30 \%$. Nearly $70 \%$ of the unemployed are long-term unemployed (Kosovo Progress Report, 2014).

Regarding the theoretical explanation of the relationship between unemployment and NPL is when there is an increase of unemployment in the country that negatively affects the amount of income which reduces their opportunity to pay the debts.It is clear that when a person loses his job he cannot return the credit, similarly an increase in unemployment in a country's economy adversely affects the demand for the products of firms that ultimately affect the production / sales companies. Eventually, it leads to a decline in income of firms and the fragile conditions of debt (Louzis, Vouldis and Metaxas, 2010).

\section{Results and Disussion}

The findings of the survey have been divided in two parts, in the first part has been introduced the perception of bank's employees for the impact of macroeconomic variables and creditability policies in NPL variable, whereas in the second part has been presented the perception of credits borrowers for macroeconomic variables and the maturity in incresing NPL. 


\subsection{The view of the bank employees}

To measure the impact of independent variables (GDP rate, interest rate, inflation rate, unemployment rate, maturity and application of grace period) in NPL the dependent variable is used in multiple regression analysis, these results are presented below, see Table 1.

Table.1.

The analysis of multiple regression for dependent variable of "NPL"

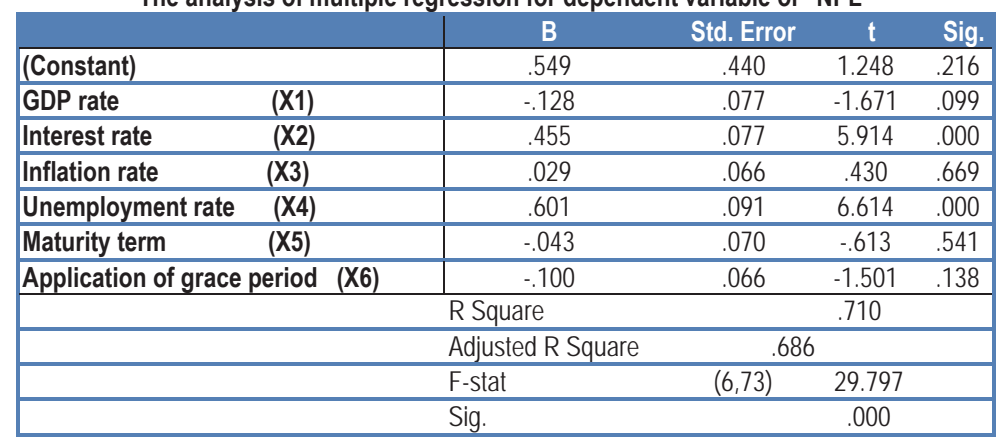

F critique for the scale of freedom $(6,73)$ is 3.07 whereas real $F$ is 29.797 which implies that the model is important statistically with the level of significance $a=0.05$

According to regression analysis independent variables enter in the analysis through explaining $68.6 \%$ of the dependent variables in NPL.

Using weights of non standardized regression, regression equation can be presented as follows:

$\hat{Y}=0.549-0.128 X_{1}+0.455 X_{2}+0.029 X_{3}+0.601 X_{4}-0.043 X_{5}-0.100 X_{6}+\varepsilon$

GDP rate - the regression analysis of GDP level is inversely proportional to the NPL, if other variables remained unchanged according to the equation for every 0.1 unit of GDP increase, it will be a decrease of $1.28 \%$ in NPL. If the GDP increases with it will increase the probability of borrowers to pay off any debt within the stipulated time.

If the explanation is continued of the negative relation in between GDP and NPL, with data from the literature, it has been found that the growth of gross domestic product usually increases revenue which ultimately increase the capacity of the borrower's loan to pay the debts, which contributes to reduce non-performing loan and vice versa ( Khemraj and Pasha, 2009)

Interest- rate according to bank employees' perceptions the link in between the interest rate and NPLs is positive (in proportion), which would mean that with the interest rate increase to 0.1 will increase the possibility of failure to return the loans for $4.55 \%$, if other variables remain unchanged, it follows by reason that as big as the cost of credit is the more difficult it will be to pay off the loan.

The same explanation also is given by the authors Sinkey and Greenwalt (1991), from a survey in the United States. They found a positive relationship between the rate of losing loan and high interest norms.

When there is an increase in debt and higher interest rate payments, then the effect of interest rates should be positive in the growth of problem loans (Bofondi and Ropel, 2011).

Inflation- rate from survey results also revealed that the rate of inflation is positive about the growth of failure to return bank loans, the data show that for each 0.1 unit change in the inflation rate there is a difference of $0.29 \%$ rate NPL, if other variables remained unchanged. The higher the inflation rate may be as high would be the rate of NPL in total loans report.

Unemployment- rate banking employees have classified as the most important variable which has the highest positive correlation of all other macroeconomic variables with the failure of returning the bank loans (NPL). The results of the research, the analysis of regression rate unemployment is on the right ratio (positive) the failure to return the bank loans (NPLs) for each 0.1 unit change in the unemployment rate if other variables remained unchanged dependent variable in our case NPL differs $6.01 \%$.

Same results where unemployment is positively related to NPL have been showed in previous researches by the authors (Salas and Suarina, 2002; Ryan and dhal, 2003; Fofack, 2005; and Jimenez and SAURINA, 2005). 
Lending policies, the maturity and grace application period- From the results of the survey shows that these two independent variables are related negatively with the failure of retuning the bank loan (NPL). By increasing the duration of the payment of the loan will have installment payment reduction as a result the borrower will have a greater opportunity to pay the loan within the prescribed period. Also if grace period is applicable, which gives a space of time borrowers to early loan repayment, this option helps the borrowers to rotate with borrowed money in order to increase his own income or business of his own, which later will serve for the return of regular bank loan.

The structure of loans by maturity in Kosovo remains similar to previous periods. Most of the loans continues to be dominated by loans with longer maturity, loans with maturity 'over 2 years' in June 2014 represented $67.6 \%$ of total loans (68.0\% in June 2013). Medium-term loans maturing ('1 to 2 years') continue to have the lowest share within the credit, being represented by $7.3 \%$ in June 2014 (7.8\% in June 2013). While loans with shorter maturity ("up to 1 year") recorded slight expansion in participation, representing $25.1 \%$ of total loans in June 2014 (24.2\% in June 2013), (CBK, 2014).

\subsection{The point of view of loan Borrowers}

Even borrowers views are entered into the regression analysis, to test the influence of independent variables (GDP, interest rate, inflation rate, unemployment rate and maturity) to the borrower.If these factors move in the opposite direction of the growth of borrowers income then as a result the inability of the borrower to return depts that he has for the bank, then the borrowers return to bad creditors that in our case it was coded as dependent variables in NPL.

Table 2.

The analysis of multiple regression for dependent variable of "NPL"

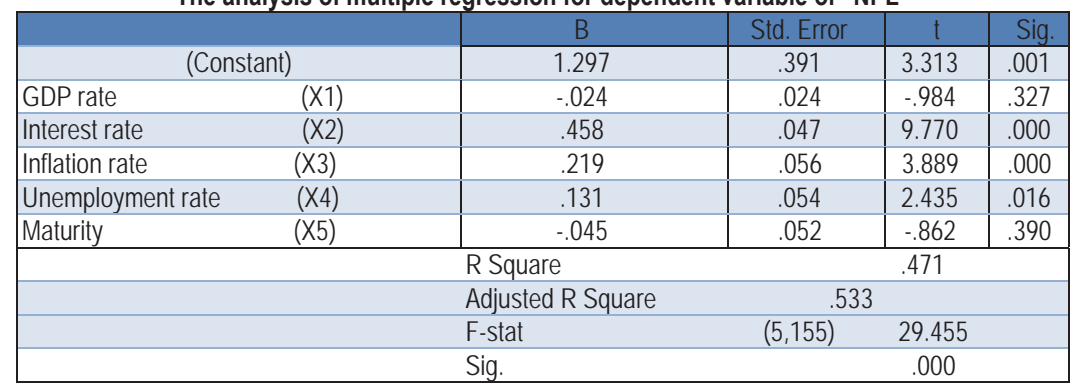

Using free weights of standardized regression, regression equation can be presented as follows:

$\hat{Y}=1.297-0.024 X_{1}+0.458 X_{2}+0.219 X_{3}+0.131 X_{4}-0.045 X_{5}+\varepsilon$

$F$ critique for the scale of freedom $(5,155)$ is 3.14 while real $F$ is 29,455 which means that the model is statistically important with the level of significances $\alpha=0.05$.

According to regression analysis of independent variables that are included in the analysis explain that $47.1 \%$ of the dependent variable in NPL.

Even according to the borrowers 'perception results indicated that they are the same logic with the bank employees' perceptions, independent variables (BPB and the maturity) are negatively associated with the dependent variable NPL, with increased gross product Internal extension of the maturity period will be reduced the rate of nonperforming loans in relation with the total loans, while other independent variables (unemployment rate, interest rates and inflation rates) are positively associated with NPL, with the growth of these independent variables would have increased the rate of non-performing loans in Kosovo.

Results emerged coherent information, the data taken from the questionnaires of the borrowers implied that the main reason why they fail to return bank loans is that they percieve the interest rates high. The application of a higher interest rate discourages individuals or businesses to obtain loans in order to use this credit towards the growth of their income, such a situation takes place in a period of economic recession, as a result of revenue reduction will increase the likelihood that individuals and businesses fail to repay their debts.

Regression analysis indicated that for each 0.1 unit increase in interest rate will have $4.58 \%$ increase in NPLs and vice versa, if the other variables remain unchanged. 


\section{Conclusion}

From the survey results, we managed to find out some information on the impact of macroeconomic factors and credit policies in nonperforming credits in Kosovo.

According to data from the regression analysis of the results of two questionnaires collected from bank employees and the borrowers that have non-performing loans, the results showed that independent variables (GDP, maturity and grace apply your period) have a negative relationship (in proportion oblique) with dependent variable NPL. If the GDP increases, the maturity and grace period will have a reduction in the NPL rate on total loans ratio. Negative link between GDP and NPL expressed by the authors (Espinosa and Prasad, 2010; Lawrence 1995; Williamson, 1987; Salas and Suarina, 2002; Ryan and dhal, 2003; Fofack, 2005; and Jimenez and SAURINA, 2005).

While other macroeconomic variables (interest rate, inflation rate and unemployment rate) by regression analysis see about the positive (right) with the dependent variable in NPI. If the interest rate rises, it increases the cost of credit taken which would be more difficult to be paid and as a result we will have growth of NPL. Positive link between interest rates and NPL in their research also was given by (Espinosa and Prasad, 2010; Adebola et al. 2011). Positive correlation between the unemployment rate and consumer prices, inflation against problem loans also showed (Babouček and Jančar, 2005). Also authors (Louzis, Vouldis and Metaxas, 2010) found positive correlation between unemployment and NPL. This study makes a significant contribution to the scientific and academic value, to the macroeconomic factors in the failure of returning the bank credits in Kosovo, in the region and beyond.

\section{Recomandation}

The recommendations given in this paper are based on the results of this survey and are aimed to decrease NPL rate in Kosovo.

Recommendation directed to the Central Bank of Kosovo - this recommendation is made as CBK has a significant impact on the national economy. The advice given to it is to decrease the rate of interest on commercial banks operating in Kosovo. But this change of norms of interest must be in compliance with the inflation rate.

Recommendations for economic or financial policies- government should draft policies for the stability of prices, and employment growth in the country through employment development platforms. This can be done using strategies that affect business development, stimulate productive enterprises and subsidize agriculture.All these affect the economic development of a country. Also it needs to draft laws that aim to protect the workers of the private sector, notably where the salary is low and if the inflation rate increases this category cannot withstand their obligations.

Recommendation for banks operating in Kosovo-the advice for banks is to allocate the policies to appropriate credit policies, to give long-term loans (to extend the period of maturity of the loan) and apply the grace period for business credits which enables new corporation to develop economic activity for a certain period of time, by means of a loan from the bank without having the burden of loan repayment. The extension of the maturity period and the application of grace periods in the study resulted to affect the reduction of NPL in Kosovo.

\section{References}

Adebola, S.S, Sulaiman, W., Yusoff, W., Dahalan, J. (2011). An ARDL Approach to the determinants of nonperforming loans in Islamic banking system in Malaysia. Arabian Journal of Business and Management Review, 1(2), 20-30;

Babouček, I. and M. Jančar (2005). Effects of Macroeconomic Shock to the Quality of the Aggregate Loan Portfolio. Czech National Bank, Working Paper Series, no. 1, pp. 1 - 62;

World bank, (2014). (http://data.worldbank.org/indicator/FR.INR.LEND); Banka Qendrore e Republikës së Kosovës (2014). Raporti i Stabilitetit Financiar Nr. 6, Prishtinë: BQK.

Bofondi, M., Ropele, T. (2011). Macroeconomic determinants of bad loans: evidence from Italian banks. Occasional Papers, 89;

Dash, M., Kabra, G. (2010). The determinants of non-performing assets in Indian commercial bank: An econometric study. Middle Eastern Finance and Economics, iss.7, 94-106;

Espinoza, R., Prasad, A. (2010). Nonperforming Loans in the GCC Banking Systems and their Macroeconomic Effects. IMF Working Paper 10/224 (Washington: International Monetary Fund);

Fofack, H. (2005). Non-performing loans in sub-Saharan Africa: Causal Analysis and Macroeconomic Implications. World Bank Policy Research Working Paper, $n^{\circ} 3769$;

International Monetary Fund. (2014). World Economic Outlook, WOE Database;

Jimenez, G., and J. Saurina. (2005). Credit cycles, credit risk, and prudential regulation. Banco de Espana, January.

Jimenez, G., Saurina J. (2006). Credit cycles, credit risk, and prudential regulation. International Journal of Central Banking, 2(2), 65-98;

Khemraj Tarron, and Pasha S. (2009). The determinants of non-performing loans: an econometric case study of Guyana. Presented at 
the Caribbean Centre for Banking and Finance Bi-annual Conference on Banking and Finance, St. Augustine, Trinidad;

Kosovo Progress Raport, European Kommission, October (2014) (http://ec.europa.eu/enlargement/pdf/key_documents/2014/20141008kosovo-progress-report_en.pdf);

Lawrence, E. C., (1995). Consumer Default and the Life Cycle Model. Journal of Money Credit and Banking, 27, 939-954;

Louzis, D.P., Vouldis, A.T., Metaxas, V.L. (2010). Macroeconomic and bank-specific determinants of non-performing loans in Greece: a comparative study of mortgage, business and consumer loan portfolios. Bank of Greece, Working Paper, n`118;

Nkusu, M. (2011). Nonperforming Loans and Macrofinancial Vulnerabilities in Advanced Economies. IMF Working Paper 11/161 (Washington: International Monetary Fund);

Rajan, R. and S.C. Dahl. (2003). Non-performing Loans and Terms of Credit of Public Sector Banks in India: An Empirical Assessment. Occasional Papers, 24:3 Reserve Bank of India;

Rinaldi, L., Sanchis-Arellano, A., (2006). Household Debt Sustainability: What Explains Household Non-performing Loans, An Empirical Analysis. ECB Working Paper. PDF;

Salas, V., Saurina, J. (2002). Credit risk in two institutional regimes: Spanish commercial and savings banks. Journal of Financial Services Research, 22 (3), 203-224;

Sinkey, Joseph F., and Mary B. Greenawlat. (1991). Loan-Loss Experience and Risk- Taking Behaviour at Large Commercial Banks. Journal of Financial Services Research, 5(1): 43-59;

Williamson, S. (1987). Financial Intermediation, Business Failures, and Real Business Cycles. Journal of Political Economy, 95 (6), 1196-1216.

\section{Appendix}

Table 3.

"The perception of bank employees"

Correlations

\begin{tabular}{|c|c|c|c|c|c|c|}
\hline $\begin{array}{l}\text { Pearson correlation } \\
\text { Sig } 2 \text { tailed }\end{array}$ & GDP rate & Interest rate & Inflation rate & Unemployment rate & Maturity & Application of grace period \\
\hline GDP rate & 1 & & & & & \\
\hline Interest rate & .110 & 1 & & & & \\
\hline Inflation rate & .048 & .008 & 1 & & & \\
\hline Unemployment rate & .095 & $.547^{\star \star}$ & -.004 & 1 & & \\
\hline Maturity & $.397^{\star \star}$ & .052 & .005 & .203 & 1 & \\
\hline Application of grace period & $.263^{*}$ & .05 & -.103 & .166 & -.040 & 1 \\
\hline
\end{tabular}

${ }^{*}$. Correlation is significant at the 0.01 level (2-tailed).

*. Correlation is significant at the 0.05 level (2-tailed).

Table 4.

"Borrowers perception"

Correlations

\begin{tabular}{|c|c|c|c|c|c|}
\hline $\begin{array}{l}\text { Pearson correlation } \\
\text { Sig } 2 \text { tailed }\end{array}$ & GDP rate & Interest Rate & Inflation rate & Unemployment rate & Maturity \\
\hline GDP rate & 1 & & & & \\
\hline Interest rate & -.001 & 1 & & & \\
\hline Inflation rate & .113 & $.256^{\star \star}$ & 1 & & \\
\hline Unemployment rate & -.018 & .003 & -.010 & 1 & \\
\hline Maturity & $-.159 *$ & .056 & .107 & .001 & 1 \\
\hline
\end{tabular}

**. Correlation is significant at the 0.01 level (2-tailed).

*. Correlation is significant at the 0.05 level (2-tailed).

As shown in Tables 3 and 4, the correlation between independent variables is within the limits $(-0.7$ to 0.7$)$, which means that we have not multicollinearity between variables tested. 